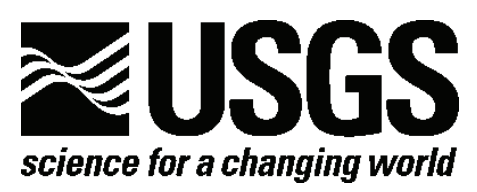

National Water Availability and Use Program

\title{
An Online Interactive Map Service for Displaying Ground- Water Conditions in Arizona
}

\author{
By Fred D Tillman, Stanley A. Leake, Marilyn E. Flynn, Jeffrey T. Cordova, and Kurt T. Schonauer
}

Open-File Report 2007-1436

U.S. Department of the Interior

U.S. Geological Survey 


\section{U.S. Department of the Interior \\ DIRK KEMPTHORNE, Secretary}

\section{U.S. Geological Survey \\ Mark D. Myers, Director}

U.S. Geological Survey, Reston, Virginia 2007

For product and ordering information:

World Wide Web: http://www.usgs.gov/pubprod

Telephone: 1-888-ASK-USGS

For more information on the USGS-the Federal source for science about the Earth,

its natural and living resources, natural hazards, and the environment:

World Wide Web: http://www.usgs.gov

Telephone: 1-888-ASK-USGS

Suggested citation:

Tillman, F.D, Leake, S.A., Flynn, M.E., Cordova, J.T., Schonauer, K.T., 2007, An online interactive map service for displaying ground-water conditions in Arizona: U.S. Geological Survey Open-File Report 2007-1436 p. 16 [http://pubs.usgs.gov/of/2007/1436/].

Any use of trade, product, or firm names is for descriptive purposes only and does not imply endorsement by the U.S. Government.

Although this report is in the public domain, permission must be secured from the individual copyright owners to reproduce any copyrighted material contained within this report. 


\section{Contents}



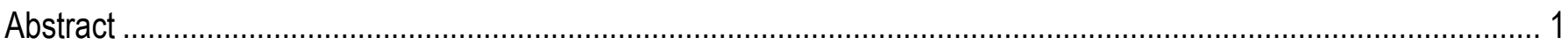

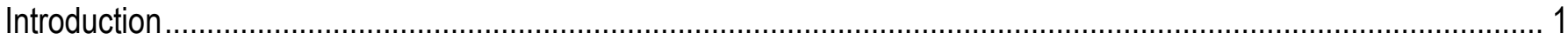

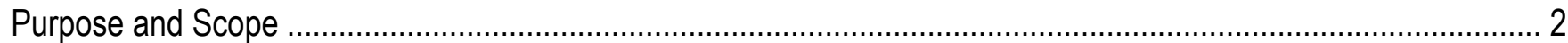

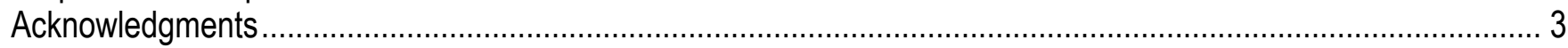

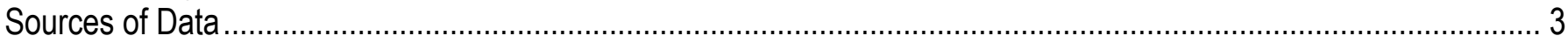

Creation and Presentation of Layers of Information on IMS System ………................................................... 5

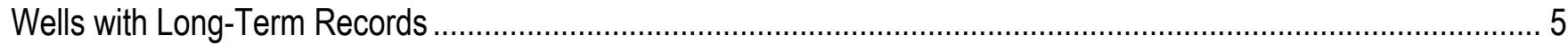

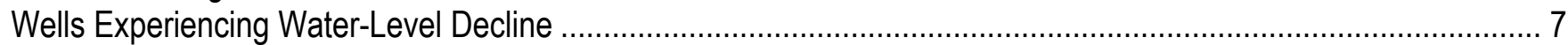

Wells Experiencing Water-Level Rise ..................................................................................................... 7

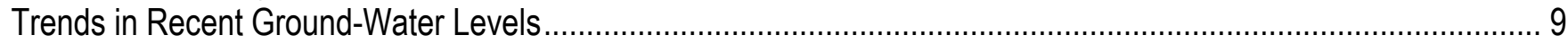

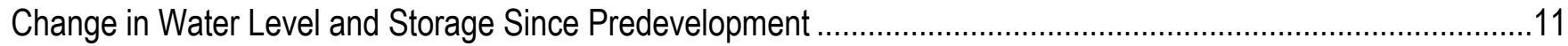

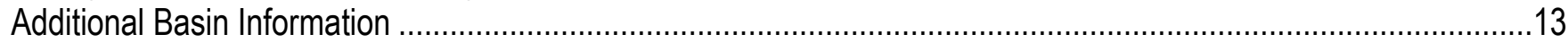

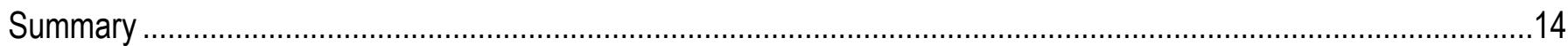

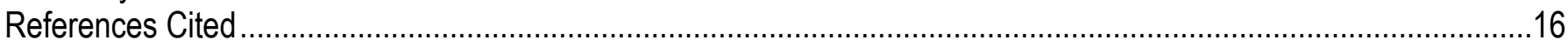

\section{Figures}

Figure 1.Map of Arizona showing basins with completed analyses of ground-water conditions and results made available on the interactive map service (IMS) . ................................................................................ 4

Figure 2.Screen capture of Arizona Ground-Water Conditions interactive map service demonstrating "Wells With



Figure 3.Example hydrograph of a well with a long-term record. Hydrographs are accessed through hyperlinks to the

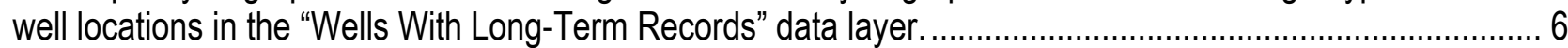

Figure 4.Screen capture of Arizona Ground-Water Conditions interactive map service demonstrating "Wells With Water-Level Decline - Prior to 1997" data layer................................................................................. 8

Figure 5.Example hydrograph of a well experiencing water-level decline prior to 1997. Hydrographs are accessed through hyperlinks to the well locations in the "Wells With Water-Level Decline - Prior to 1997" data layer. ... 8

Figure 6.Screen capture of Arizona Ground-Water Conditions interactive map service demonstrating "Wells With Water-Level Rise - Since 1997" data layer.

Figure 7.Example hydrograph of a well continuing to experience a rise in water-level after January 1, 1997. Hydrographs are accessed through hyperlinks to the well locations in the "Wells With Water-Level Rise Since-1997" data layer.

Figure 8.Screen capture of Arizona Ground-Water Conditions interactive map service demonstrating "Trends in Recent Ground-Water Levels" data layer.

Figure 9.Example hydrograph of a well experiencing a rising recent trend in water level. Hydrographs are accessed through hyperlinks to the recent-trend polygons in the "Trends in Recent Ground-Water Levels" data layer. .12

Figure 10.Screen capture of Arizona Ground-Water Conditions interactive map service demonstrating "Change in Water Level Since Predevelopment" data layer.

Figure 11.Example page of "basin information" including recent pumpage totals, current and projected population (by county) and a brief bibliography for further reading. These pages are accessed through hyperlinks to the basin name in the "Other Information" drop-down list. 


\section{Conversion Factors}

\section{Inch/Pound to SI}

\begin{tabular}{lll}
\hline \multicolumn{1}{c}{ Multiply } & \multicolumn{1}{c}{ By } & \multicolumn{1}{c}{ To obtain } \\
\hline Length & & \\
\hline foot (ft) & 0.3048 & meter $(\mathrm{m})$ \\
mile (mi) & 1.609 & kilometer $(\mathrm{km})$ \\
\hline Area & & \\
\hline acre & 0.4047 & hectare $(\mathrm{ha})$ \\
acre & 0.4047 & square hectometer $\left(\mathrm{hm}^{2}\right)$ \\
\hline Volume & & \\
\hline gallon (gal) & 3.785 & liter $(\mathrm{L})$ \\
gallon (gal) & 0.003785 & cubic meter $\left(\mathrm{m}^{3}\right)$ \\
acre-foot (acre-ft) & 1,233 & cubic meter $\left(\mathrm{m}^{3}\right)$ \\
\hline Flow rate & & \\
\hline gallon per minute (gal $/ \mathrm{min})$ & 0.06309 & liter per second $(\mathrm{L} / \mathrm{s})$ \\
\hline
\end{tabular}

Vertical coordinate information is referenced to the National Geodetic Vertical Datum of 1929 (NGVD 29). Horizontal coordinate information is referenced to the North American Datum of 1927 (NAD 27).

Altitude, as used in this report, refers to distance above the vertical datum. 


\title{
An Online Interactive Map Service for Displaying Ground-Water Conditions in Arizona
}

\author{
By Fred D Tillman, Stanley A. Leake, Marilyn E. Flynn, Jeffrey T. Cordova, and Kurt T. Schonauer
}

\begin{abstract}
Monitoring the availability of the nation's ground-water supplies is of critical importance to planners and water managers. The general public also has an interest in understanding the status of ground-water conditions, especially in the semi-arid Southwestern United States where much of the water used by municipalities and agriculture comes from the subsurface. Unlike surface-water indicators such as stage or discharge, ground-water conditions may be more difficult to assess and present. Individual well observations may only represent conditions in a limited area surrounding the well and wells may be screened over single or multiple aquifers, further complicating singlewell measurement interpretations. Additionally, changes in ground-water conditions may involve time scales ranging from days to many years, depending on recharge, soil properties and depth to the water table. This lack of an easily identifiable ground-water property indicative of current conditions combined with differing time scales of water-level changes makes the presentation of ground-water conditions a difficult task, particularly on a regional basis. One approach is to spatially present several indicators of ground-water conditions that address different time scales and attributes of the aquifer systems. In this report, we describe a publicly-available online interactive map service that presents several different layers of ground-water-conditions information for the alluvial basins in the Lower Colorado River Basin in Arizona (http://montezuma.wr.usgs.gov/website/azgwconditions/). These data layers include wells experiencing water-level decline, wells experiencing water-level rise, recent trends in ground-water levels, change in water level since predevelopment and change in storage since predevelopment. Recent pumpage totals and projected population numbers are also provided for ground-water basins and counties in the region of the Lower Colorado River in Arizona along with a bibliography of U.S. Geological Survey reports for those seeking further information. The methods used to create these data layers are explained with illustrations of example information available on the Web site.
\end{abstract}

\section{Introduction}

As ground water is increasingly developed in the Lower Colorado River Basin in Arizona, information on the effects of ground-water withdrawals is needed for assessment of water availability. Extensive pumping of ground water for irrigation and public-supply uses has generally lowered ground-water levels in many areas of the Lower Colorado River Basin. Rapid development of aquifers in the Lower Colorado River Basin began in the mid-twentieth century. Availability of deep-well turbine pumps and rural electricity allowed development of agriculture in desert basins that receive minimal rainfall. Ground-water withdrawals in subsequent decades caused water-level declines of several hundred feet in many aquifers. Individual basin studies have 
mapped declines for some aquifers and some time periods, but a consistent regional depiction of the declines and associated storage changes has not been done in recent years. More than 20 years ago the U.S. Geological Survey (USGS) published a nationwide map indicating areas of major waterlevel change (U.S. Geological Survey, 1984) and maps have been prepared by the USGS for select areas of the Lower Colorado River Basin and other areas of the United States (Anderson, 1995). Despite the need for better and updated information, however, no update of ground-water conditions has been completed in the intervening 20 years that parallels the ongoing analysis of surface-water resources. In an effort to address this need, the USGS has created a pilot interactive Web site to present ground-water conditions in the most developed alluvial basins in Arizona.

The Arizona Ground-Water Conditions interactive mapping service (IMS) Web site has an underlying shaded-relief base map with various political, geographic, and hydrologic features that can be viewed selectively. Different types of ground-water information that can be viewed are grouped into "layers". The layers of information available span both recent and historic time periods. A layer showing wells with long-term records provides the location of wells that have hydrographs extending back to the earliest records in the basin. A layer of recent trends in groundwater levels presents areal representation of trends in ground-water conditions over the last 10 years. Information on wells experiencing decline is divided into two layers: 1.) a layer that contains information on wells whose decline of greater than 75 feet occurred prior to January 1, 1997 and 2.) a layer with information on wells whose decline of greater than 75 feet occurred after this time. Wells experiencing water-level rises are likewise separated into two layers: 1.) a layer that shows wells with greater than 50 feet of water-level rise occurring prior to January 1, 1997 and 2.) a layer showing wells with greater than 50 feet of water-level rise occurring after this time. The minimum values of water-level decline of 75 feet and water-level rise of 50 feet were chosen to produce a manageable number of wells indicating meaningful decline and rise. The date of January 1, 1997 was chosen to demarcate "recent time" for ground-water conditions in this study. All of the aforementioned data layers utilize hyperlinks to the well hydrographs, allowing users to see the data for themselves. Additionally, spatial raster images of both water-level and storage change since predevelopment are provided as layers to present interpretations of changes in these indicators since large-scale ground-water withdrawals began in the basins. Charts on recent ground-water withdrawals and population projections are also provided through the IMS Web site.

\section{Purpose and Scope}

The purpose of this study is to assemble data sets and analyses for use in understanding ground-water availability and conditions in the Lower Colorado River Basin. A special emphasis of the project is on development of methods of assessment and display of ground-water conditions from analyses of alluvial aquifers in the Lower Colorado River Basin, utilizing information available from the USGS National Water Information System (NWIS) and the Arizona Department of Water Resources' (ADWR) Groundwater Site Inventory databases. To this end, the USGS has created a publicly-available online interactive map service (IMS) to display Arizona ground-water conditions in selected basins (http://montezuma.wr.usgs.gov/website/azgwconditions/).

Nearly all of the ground-water development in the Lower Colorado River Basin has taken place in the alluvial aquifers of the Basin and Range Physiographic Province. This set of interconnected aquifers was studied in detail by the Southwest Alluvial Basins (SWAB), Regional Aquifer-System Analysis (RASA) study (Anderson, 1995). The current study builds on and updates the findings of the SWAB/RASA project. Aquifers within the study area can be 
categorized with respect to ground-water development as (a) highly developed urban areas, mainly Phoenix and Tucson; (b) highly developed agricultural areas; (c) rapidly developing rural areas; and (d) rural areas with limited development. Most of the basins in the first two categories have been grouped together to make up the State's five Active Management Areas (AMAs). In general, ground-water data are most plentiful in the AMAs, but some data exist in nearly all areas. Basins are being addressed in this project in the order of decreasing historical ground-water development according to pumpage records (Konieczki and Wilson, 1992). Analyses of several of the groundwater basins delineated by ADWR have been completed (fig. 1). Boundaries for the SWAB/RASA ground-water basins do not always align with ground-water basins delineated by ADWR. In this project, both basin designations have been used at different times and both basin boundaries are available for viewing on the IMS system. Future tasks of this study will focus on several of the remaining more-developed alluvial ground-water basins in the Lower Colorado River area of Arizona and the IMS Web site will be updated using the same approach described in this report. Updates of the IMS Web site will be dependent upon the availability of funding.

\section{Acknowledgments}

Development of the IMS Web site was funded by the USGS Water Availability and Use Program. Teri Davis and Terry Voght of ADWR, and Bill Cunningham, Kevin Dennehy, and Tom Reilly of the USGS provided valuable technical guidance at various stages of development of the system. Jeff Phillips, formerly of the USGS, was instrumental in developing ideas for presentation of data. Cheryl Partin of the USGS provided database support.

\section{Sources of Data}

Data for creating and presenting the layers of information on ground-water conditions on the IMS Web site were obtained from the USGS National Water Information System (NWIS, see http://waterdata.usgs.gov/nwis/gw) and the Arizona Department of Water Resources Groundwater Site Inventory (http://www.azwater.gov/dwr/Content/Find_by_Category/ABCs_of_Water/State_Wide_Programs/ gwsi.htm) databases. Well data were selected for individual basins from the ADWR database using the "basin name" field and were selected from NWIS using basin coordinates. Fields selected for output from the databases included site identification number, local well number, latitude and longitude of well location, water-level measurement date, water-level below land surface, waterlevel status (or remark code in ADWR database), altitude of land surface, primary use of water, hole depth, and well depth. Data from the two databases were merged into a single data file using a program written in Visual Basic for Applications ${ }^{\circledR}$ (VBA) that compares site identification numbers between the two databases and deletes any duplicate water-level observations. The program formats the water-level measurement date in the form required by subsequent programs used for creating the IMS data layers and deletes all observations that are flagged as pumping in the waterlevel status field.

Water withdrawal data for the AMAs and Irrigation Non-Expansion Areas (INAs) were obtained from ADWR. There are two categories of wells in the AMAs and INAs - exempt wells with pump capacity less than or equal to 35 gallons per minute and non-exempt wells with pump 


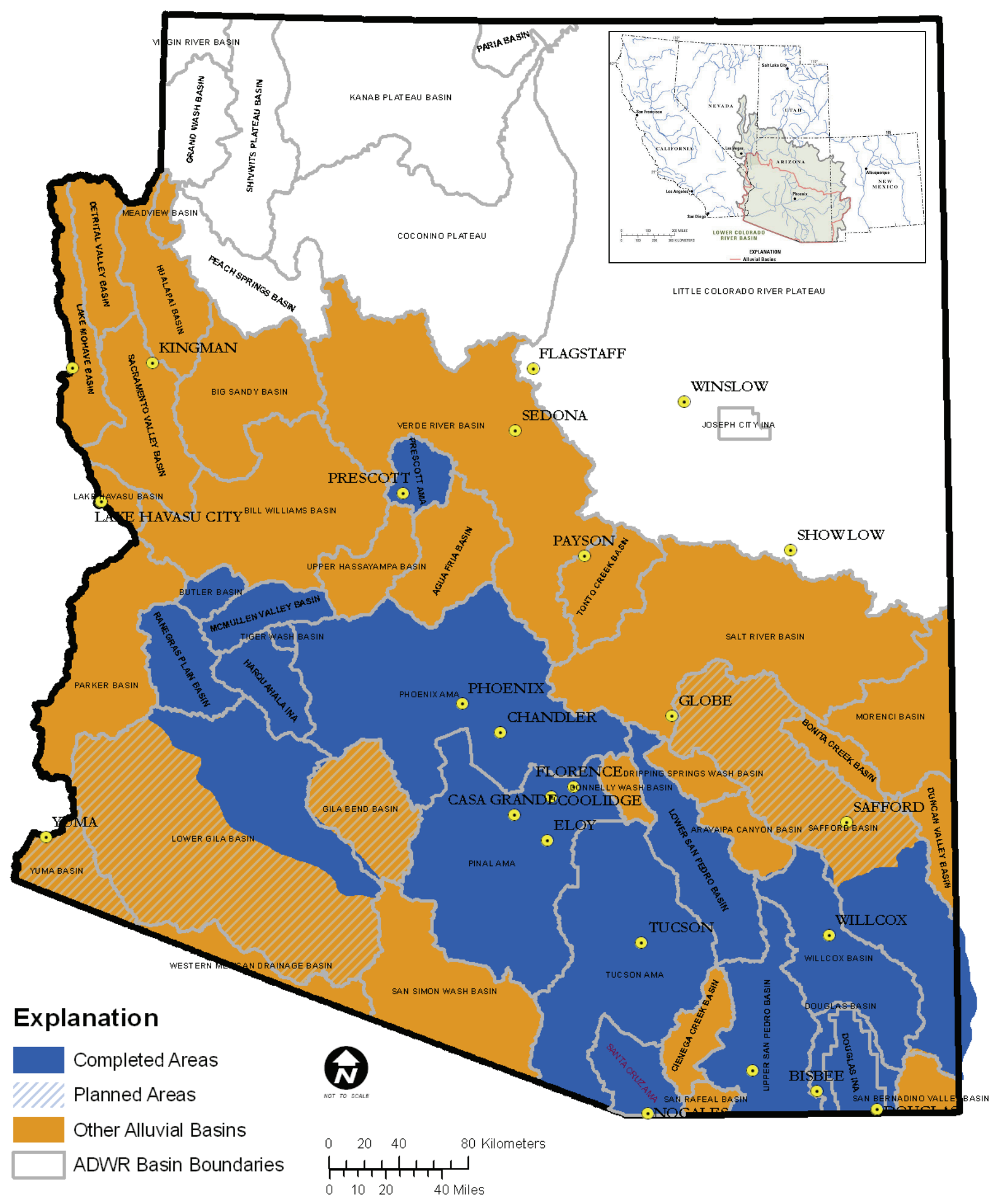

Figure 1. Map of Arizona showing basins with completed analyses of ground-water conditions and results made available on the interactive map service (IMS).

capacity greater than 35 gallons per minute. For this project, withdrawal data for the AMAs and INAs were obtained from the Wells55 Database CD which is available from the ADWR bookstore 
(http://www.water.az.gov/ecscripts/ecware.exe/catalog?id=001\&category=All\&type=A1QN11). Withdrawal data for basins outside of the AMAs and INAs were provided by the USGS water-use program in Arizona (http://az.water.usgs.gov/projects/9671-9DW/). Data from the two sources were combined and organized under four categories of water use (irrigation, municipal, mining, and thermoelectric). Population estimates for Arizona counties were provided by the Arizona Department of Economic Security (ADES, http://www.workforce.az.gov).

\section{Creation and Presentation of Layers of Information on IMS System}

\section{Wells with Long-Term Records}

This layer presents a subset of wells in the USGS and ADWR databases that have waterlevel observations spanning an extensive time period. The wells in this layer were selected by inspecting all hydrographs having observations that extend as far back in time as records are available for the basin. Categories of long-term records displayed are a) greater than 50 years, b) $25-50$ years, and c) $0-25$ years. For basins with many different long-term records in a category, only those judged to be the best and most representative are displayed. For example, in an area with many records in the range of 0 to 25 years, shorter records and records with fewer or uneven data distributions through time may not be displayed. Users wishing to see all available groundwater records should consult the ADWR and USGS databases. The intent of this layer is to provide users of the Arizona Ground-Water Conditions Web site an indication of long-term trends over historical time periods that may be affected by climate, development, or other factors. Long-term trends are investigated by analyzing available well hydrographs in each basin to determine the time period that qualifies as "historical" and to ensure that observations in intervening years are present. Creation of this layer is facilitated by two VBA programs: the first analyzes the data record for all wells and the second produces portable document format (pdf) hydrographs and a geographic information system (GIS) file for projecting the selected wells. The first program presents information on the number of wells with at least a selected minimum number of observations and the number of wells with an observation before and after selected dates. This information allows determination what period of record constitutes "long term" for a particular basin. The second program prompts the user for the latest first-observation date, the earliest last-observation date, and a minimum number of observations in a record as criteria for selecting and creating the hydrographs and a GIS data file.

The locations of wells with long-term records are presented in the IMS system as orange colored circles (fig. 2). Well locations indicated with darkest orange have records that span at least 50 years. Medium orange circles indicate wells with records that extend back between 25 and 50 years and light orange circles are wells with records only within the last 25 years. By selecting the hyperlink tool and clicking on one of the wells in the long-term records layer, one can inspect the hydrograph of the selected well (fig. 3). The header of the hydrographs present well information including site identification number, well name, longitude, latitude, altitude of the well, and well depth, if available. 


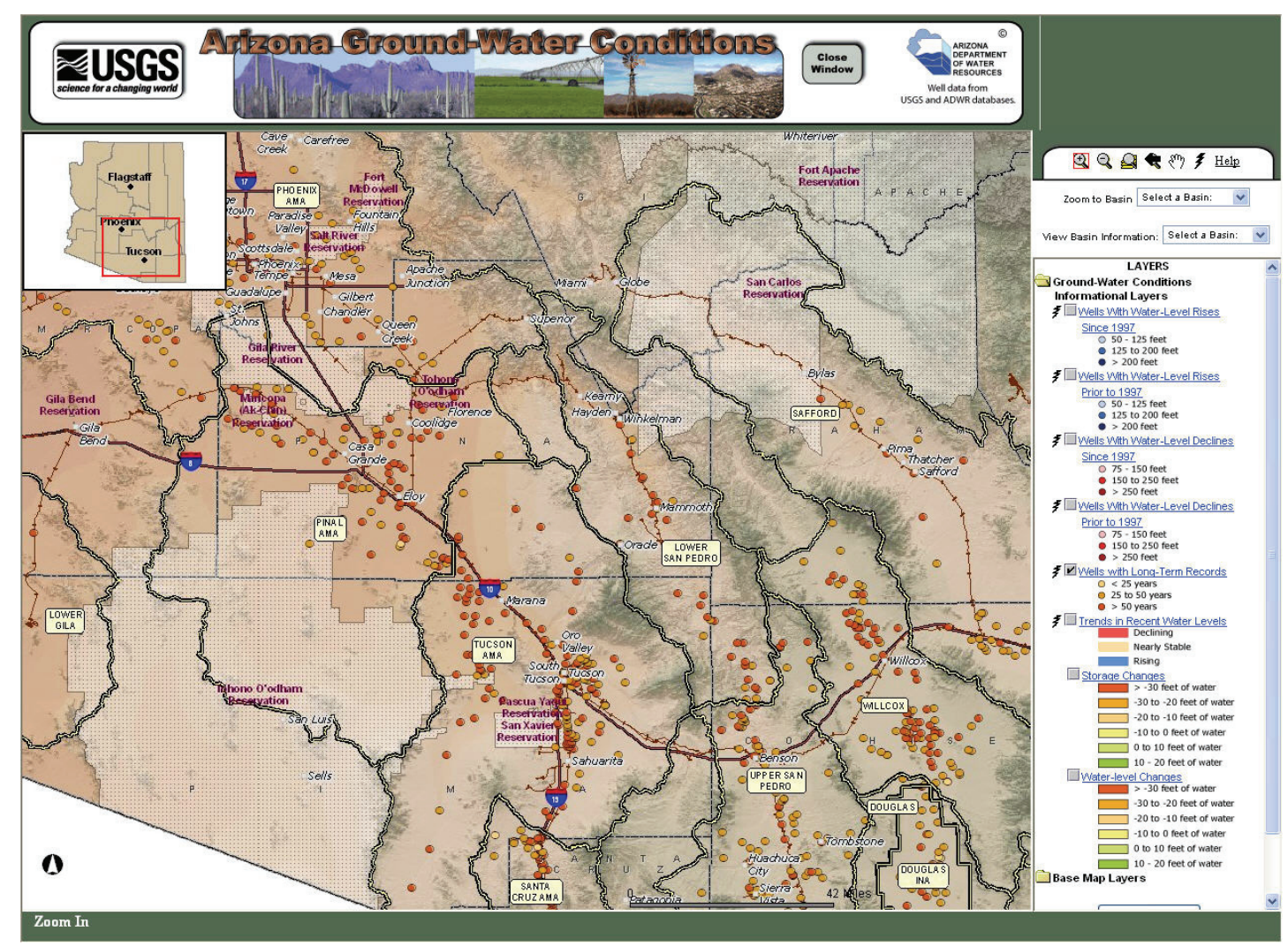

Figure 2. Screen capture of Arizona Ground-Water Conditions interactive map service demonstrating "Wells With Long-Term Records" data layer.

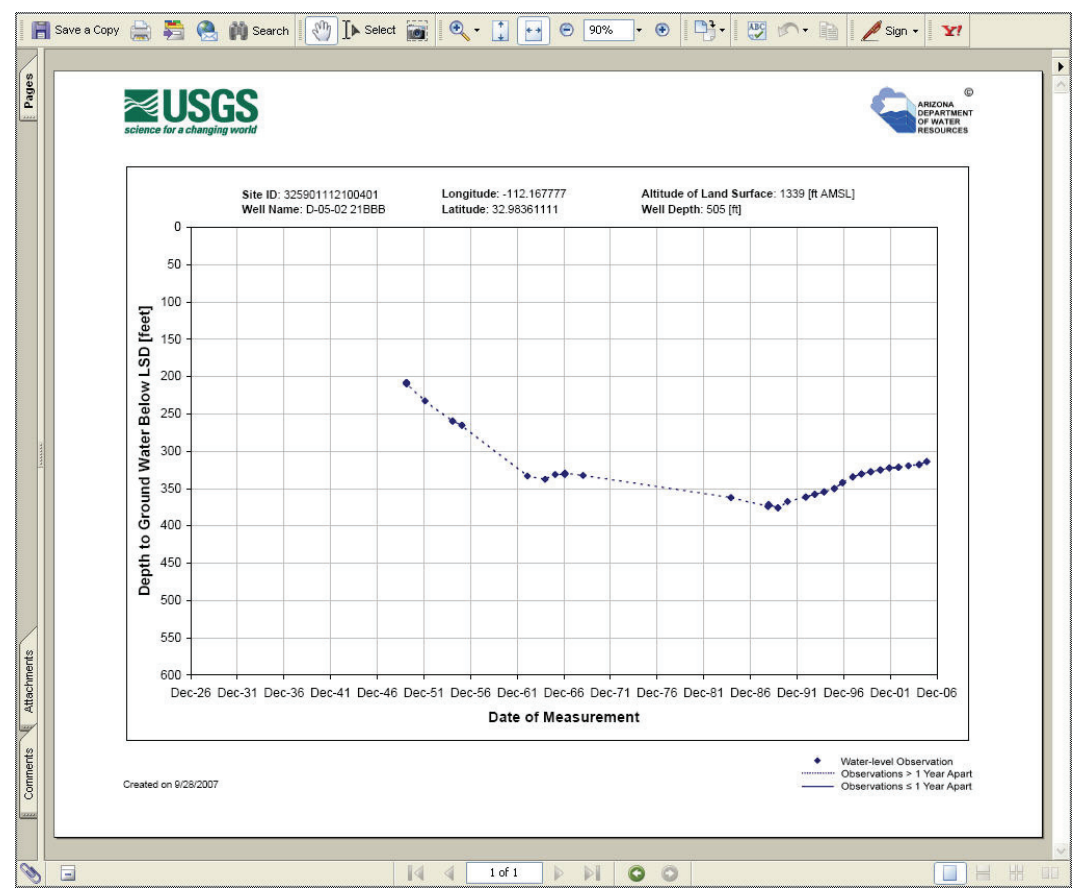

Figure 3. Example hydrograph of a well with a long-term record. Hydrographs are accessed through hyperlinks to the well locations in the "Wells With Long-Term Records" data layer. 


\section{Wells Experiencing Water-Level Decline}

Ground-water development in the Lower Colorado River Basin has caused water levels to decline in many areas. Some of these water-level declines have continued to occur during recent time while others were evident during more historical time periods. Two layers in the IMS system present subsets of wells in the USGS and ADWR databases that show declines in water levels of at least 75 feet. This minimum amount of water-level decline was chosen to produce a manageable number of wells indicating meaningful decline. These subsets of wells were determined from existing water-level observations by finding the minimum depth to ground water followed by the maximum depth to ground water and computing the difference. For the "Prior to 1997" historicaldecline layer, the maximum depth to ground water during the well's period of record must occur before "recent time," defined here as before January 1, 1997. For the "Since 1997" recent-decline layer, the maximum depth to ground water during the well's period of record must occur after January 1, 1997. The creation of these layers involved two VBA programs. The first searches for the minimum and subsequent maximum depths to ground water in each well record and creates a summary table of this information. The second program creates pdf hydrographs from wells included in the summary table, notes the observations used to calculate the decline value as well as the value itself, and produces a GIS file used by the IMS system to project the wells on the Web site. To avoid erroneous decline calculations, water levels that were flagged as having been measured during pumping conditions were excluded, a minimum of three observations were required during the decline period and all hydrographs were visually inspected before inclusion in the layers. During visual inspection of the hydrographs, any measurement that appeared to be influenced by pumping and not reflective of more regional water-level declines (that is to say a sharp change in water level between two fairly stable measurements) was excluded from the decline calculations.

The locations of wells experiencing water-level decline are presented as red colored circles with darker shades indicating greater decline (fig. 4). By selecting the hyperlink tool $F$ and clicking on one of the wells in the water-level decline layer, one can visually inspect the hydrograph of the selected well (fig. 5). The header of the hydrograph presents well information including site identification number, well name, longitude and latitude, altitude of the well, and well depth, if available. Water-level observations are displayed on the hydrograph with observations used in determining decline indicated by red lines along with the calculated decline value.

The example hydrograph (fig. 5) illustrates records from a well experiencing a water-level decline during historic time. Note that although the hydrograph shows a decline of 249 feet during historical observations, more recent observations indicate that the depth to ground water has risen from this maximum depth. Also note that decline is calculated using the maximum and minimum depths recorded. In this case, the minimum depth was the first recorded water level in the late 1950's and the maximum water level was near 1982. It is possible that ground-water levels were even higher in the area before this first observation.

\section{Wells Experiencing Water-Level Rise}

Some wells may have experienced rises in water levels during prior time periods, only to cease rising more recently. Other wells may have experienced water-level rises continuing until recent time. In an effort to discern areas that appear to indicate rising water levels, two layers displaying wells experiencing water-level rises were developed. These layers present subsets of wells in the USGS and ADWR databases that show rises in water levels of at least 50 feet. This 


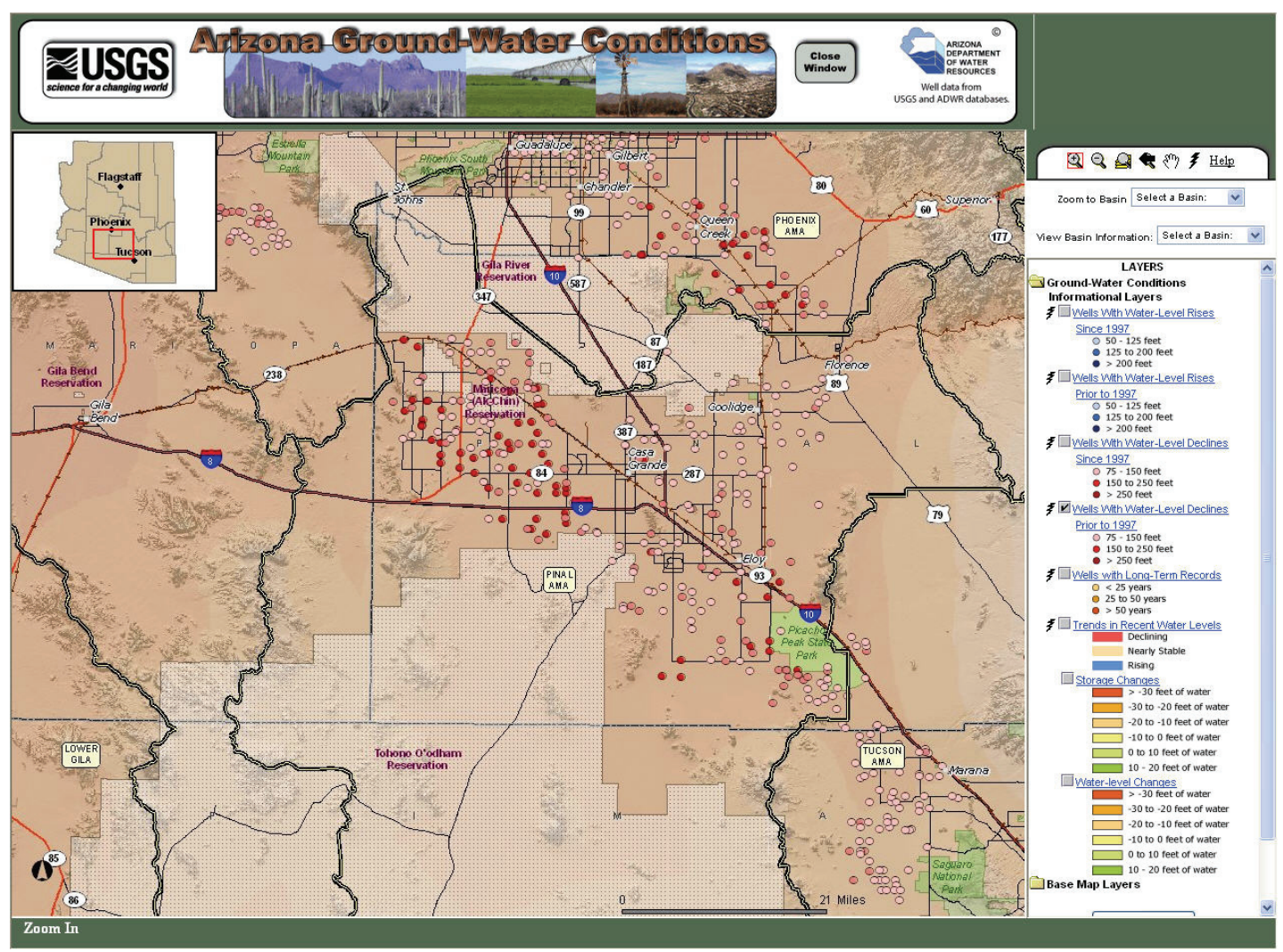

Figure 4. Screen capture of Arizona Ground-Water Conditions interactive map service demonstrating "Wells With Water-Level Decline - Prior to 1997" data layer.

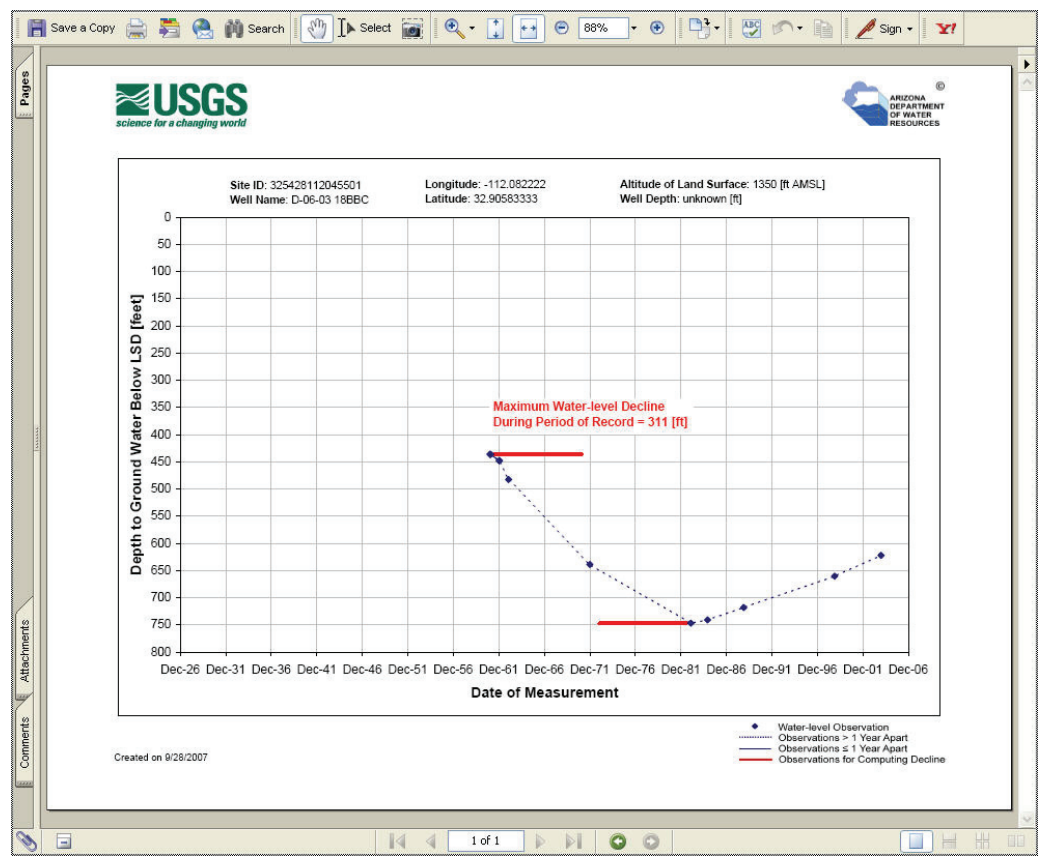

Figure 5. Example hydrograph of a well experiencing water-level decline prior to 1997. Hydrographs are accessed through hyperlinks to the well locations in the "Wells With Water-Level Decline - Prior to 1997" data layer. 
minimum amount of water-level rise was chosen to produce a manageable number of wells indicating meaningful rise. These layers of wells were determined from existing water-level observations by finding the maximum depth to ground water followed by the minimum depth to ground water and computing the difference. For the "Prior to 1997" historical-rise layer, the minimum depth to ground water during the well's period of record must occur prior to "recent time," defined here as before January 1, 1997. For the "Since 1997" recent-rise layer, the minimum depth to ground water during the well's period of record must occur after this date. To create these layers, two VBA programs are run. The first searches for the maximum and subsequent minimum depths to ground water in each well record and creates a summary table of this information. The second program creates pdf hydrographs from wells included in the summary table, notes the observations used to calculate the rise value as well as the value itself, and produces a GIS file used by the IMS system to project the wells in this layer. To avoid erroneous rise calculations, water levels that were flagged as being measured during pumping conditions were excluded, a minimum of three observations were required during the rising period, and all hydrographs were visually inspected before inclusion. During visual inspection of the hydrographs, any observation that appeared to be influenced by nearby pumping and not reflective of more regional water-level declines (that is to say a sharp change in water level between two fairly stable measurements) was excluded from the rise calculations.

The locations of wells experiencing water-level rise are presented as blue colored circles with darker shades indicating greater rise of water levels (fig. 6). A rise in water levels does not imply that ground-water levels are higher than predevelopment conditions. For an estimate of this change, see the "Ground-Water Level Change" layer in the "Change Since Predevelopment" group. Additionally, some wells that may have exhibited rising water levels in the past may show further declines in more recent periods. By selecting the hyperlink tool $\boldsymbol{F}$ and clicking on one of the wells in the rise layer, one can visually inspect the hydrograph of the selected well (fig. 7). The header of the hydrograph presents well information including site identification number, well name, longitude, latitude, altitude of the well, and well depth, if available. All water-level observations are displayed on the hydrograph with observations used in determining the rise indicated by blue lines along with the calculated value.

The example hydrograph (fig. 7) illustrates an example of a well experiencing recovery that continues after January 1, 1997. Note that although the hydrograph indicates a rise of 127.3 feet during latter observations, the depth to ground water is still below the earliest measurements in the period of record. Also note that the actual observation of the deepest depth to ground water was not used in calculation of recovery for this hydrograph. The sharp decline in this measurement compared with both the observation before and after was determined to probably be influenced by nearby pumping and not reflective of more regional water-level conditions. This observation was therefore not used in the water-level rise calculation.

\section{Trends in Recent Ground-Water Levels}

An indicator of ground-water conditions on the basis of trends in ground-water levels in recent time periods also was developed. Spatial presentation of these recent trends in water levels serve as regional indicators of ground-water conditions and identify areas having rising, stable or falling ground-water levels. Two FORTRAN programs are used in creating the recent trends data layer. The first program selects a subset of wells from the combined USGS-ADWR dataset based on user-specified date range and minimum number of observations and computes a linear trend of the water-level observations. For this layer in the IMS system, the subset of data consists of wells 


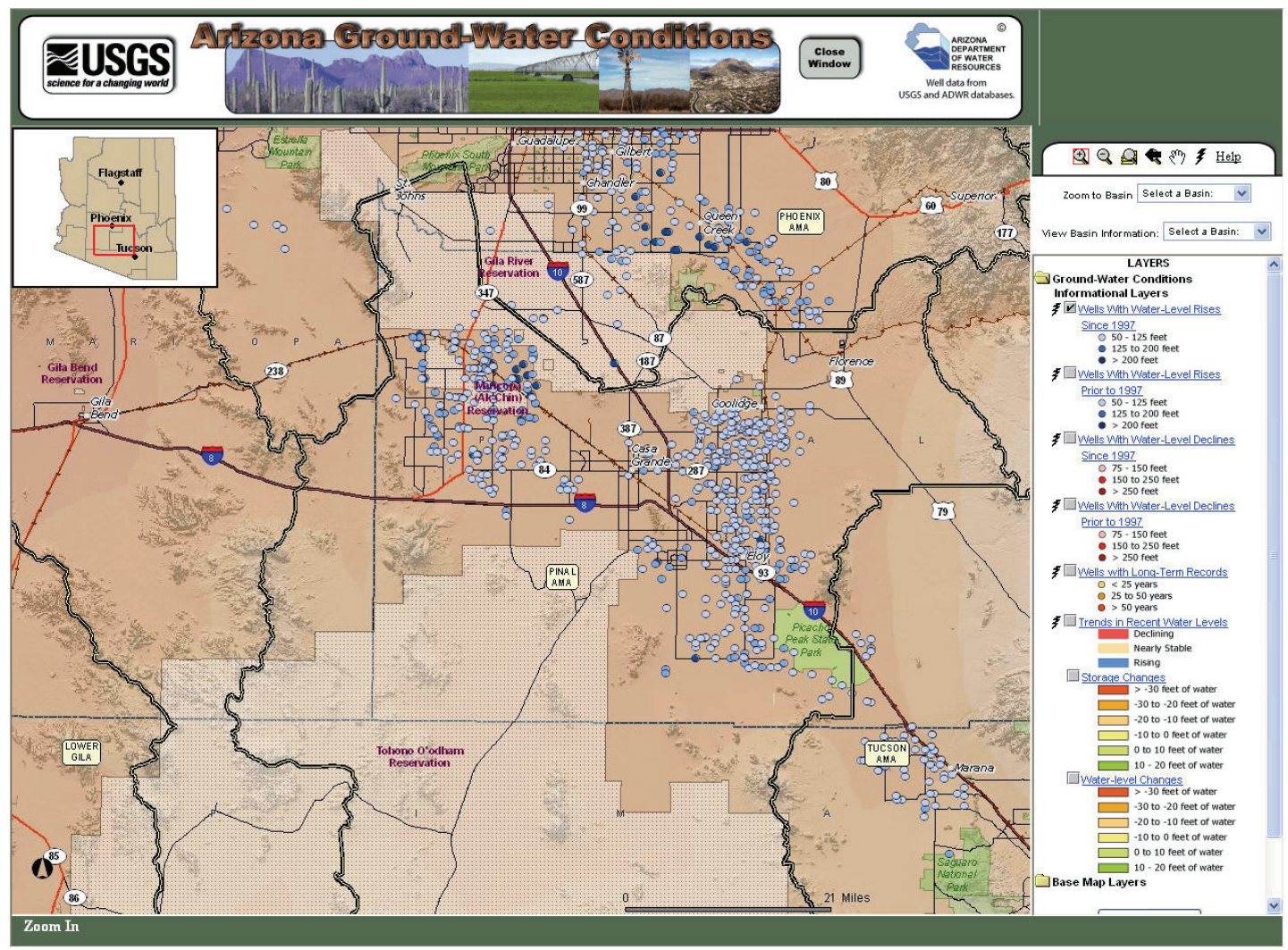

Figure 6. Screen capture of Arizona Ground-Water Conditions interactive map service demonstrating "Wells With Water-Level Rise - Since 1997" data layer.

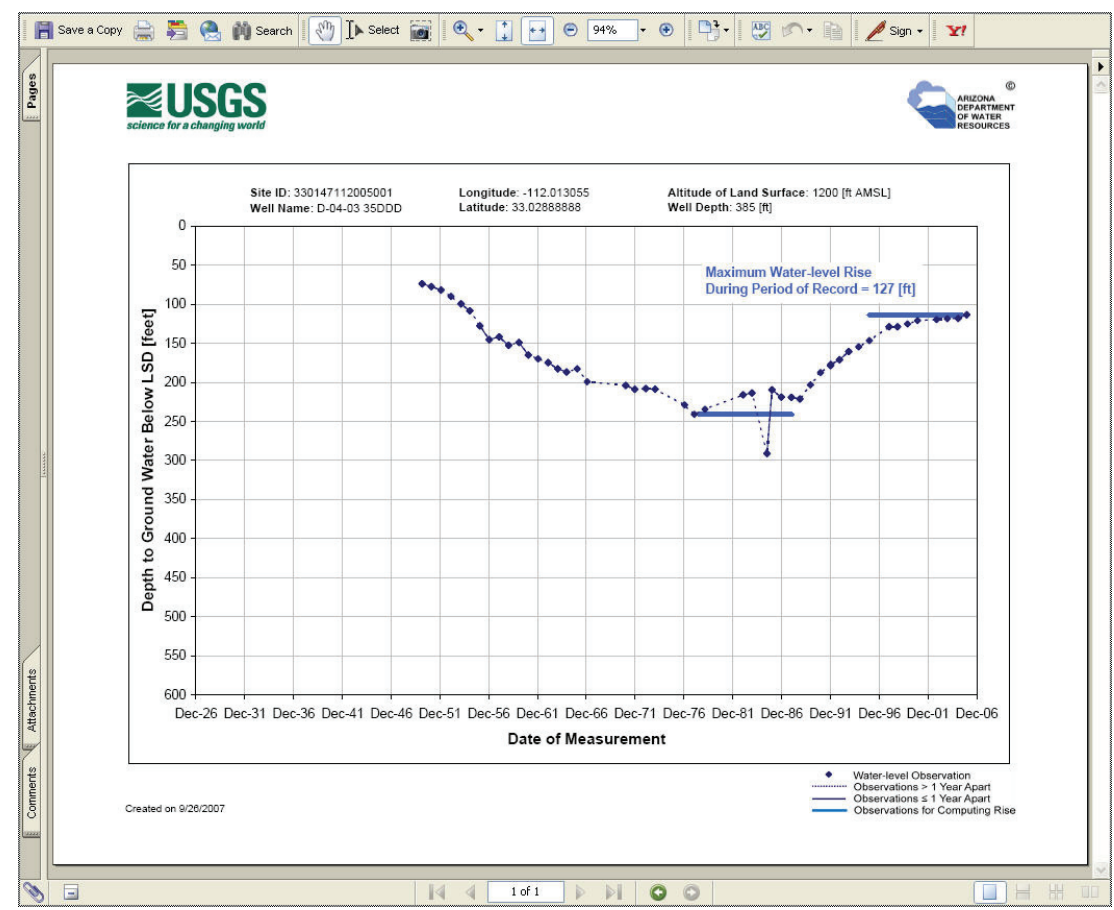

Figure 7. Example hydrograph of a well continuing to experience a rise in water-level after January 1, 1997. Hydrographs are accessed through hyperlinks to the well locations in the "Wells With Water-Level Rise Since-1997" data layer. 
with a minimum of three water-level observations between January 1, 1997 and December 31, 2006. A linear regression was performed on this subset of data and only wells meeting a goodnessof-fit $\left(\mathrm{R}^{2}\right)$ criteria were utilized in constructing the regional interpretation of the ground-water trend. For the multiple ground-water basins in the AMAs of Prescott, Phoenix, Pinal, Tucson, and Santa Cruz, the minimum $\mathrm{R}^{2}$ of the water-level trend was 0.75 . For all other areas with presumably fewer wells and observations with which to determine water-level trends, a minimum $\mathrm{R}^{2}$ of 0.5 was used in order to utilize more wells in determining trend areas. Hydrographs of all wells meeting the $\mathrm{R}^{2}$ criteria were visually inspected to ensure that the computed trend qualitatively represented the actual trend of the water levels. The areal representation of the well trends in the IMS system is accomplished by constructing modified Thiessen polygons (Mumm, 2005; Okabe et al., 1992) using the second FORTRAN program. Thiessen polygons are constructed around a well by computing the intersection of bisectors between the well and all other wells. These polygons are then modified by applying to each vertex a maximum distance of representation for a well of $3.1 \mathrm{mi}$ $(5 \mathrm{~km})$. In this way, the trend for each well is represented by an area that is constrained by this maximum distance.

The use of modified Thiessen polygon areas to represent trends in water levels from individual wells is meant for visualization purposes only and is not meant to definitively identify areas of rising, stable or falling ground-water levels. For instance, trend areas in the IMS system may extend across exposed bedrock where no actual ground water may occur. No effort was made to field verify the extent of representative trend areas and no assurance of available ground water in any of the trend areas is implied.

In the IMS system the regions of water-level trends are labeled "rising" and colored blue for water levels rising at a rate of at least $1 \mathrm{ft}(0.305 \mathrm{~m})$ per year, are labeled "falling" and colored red for water levels falling by at least $1 \mathrm{ft}$ per year and are labeled "nearly stable" and colored tan for water levels with rates of change between these two thresholds. The colored dot within each polygon is the location of the well used in determining the regional ground-water trend (fig. 8).

By selecting the hyperlink tool $\xi$ and clicking anywhere within a recent trend area, one can visually inspect the hydrograph of the well used to compute the trend in the selected region (fig. 9). The header of the hydrographs present well information including site identification number, well name, longitude, latitude, altitude of the well, and well depth, if available. Observations used in determining the linear trend are indicated beneath the computed trend line. The calculated trend is displayed as well.

\section{Change in Water Level and Storage Since Predevelopment}

Presenting information on water-level and storage change since predevelopment involves basic hydrologic analyses of historical and recent water-level surfaces. Creation of these layers begins with researching the basin area to find information on predevelopment water levels, often from historical USGS reports. Maps in these reports are scanned and georeferenced into a GIS environment and the water-level information is digitized. Well records also are searched to determine if water-level observations exist during the predevelopment era and, if so, these data are added to the report information in GIS. A surface of predevelopment water levels is created from all available historical ground-water information using an interpolation method such as inverse distance weighting or nearest neighbor. Recent water-level surfaces are generated in a similar manner by utilizing current and recent (since 2000) ground-water observations contained in the NWIS and ADWR databases. A subtraction of the current water-level surface from the predevelopment surface produces a layer of water-level change since predevelopment. Storage 


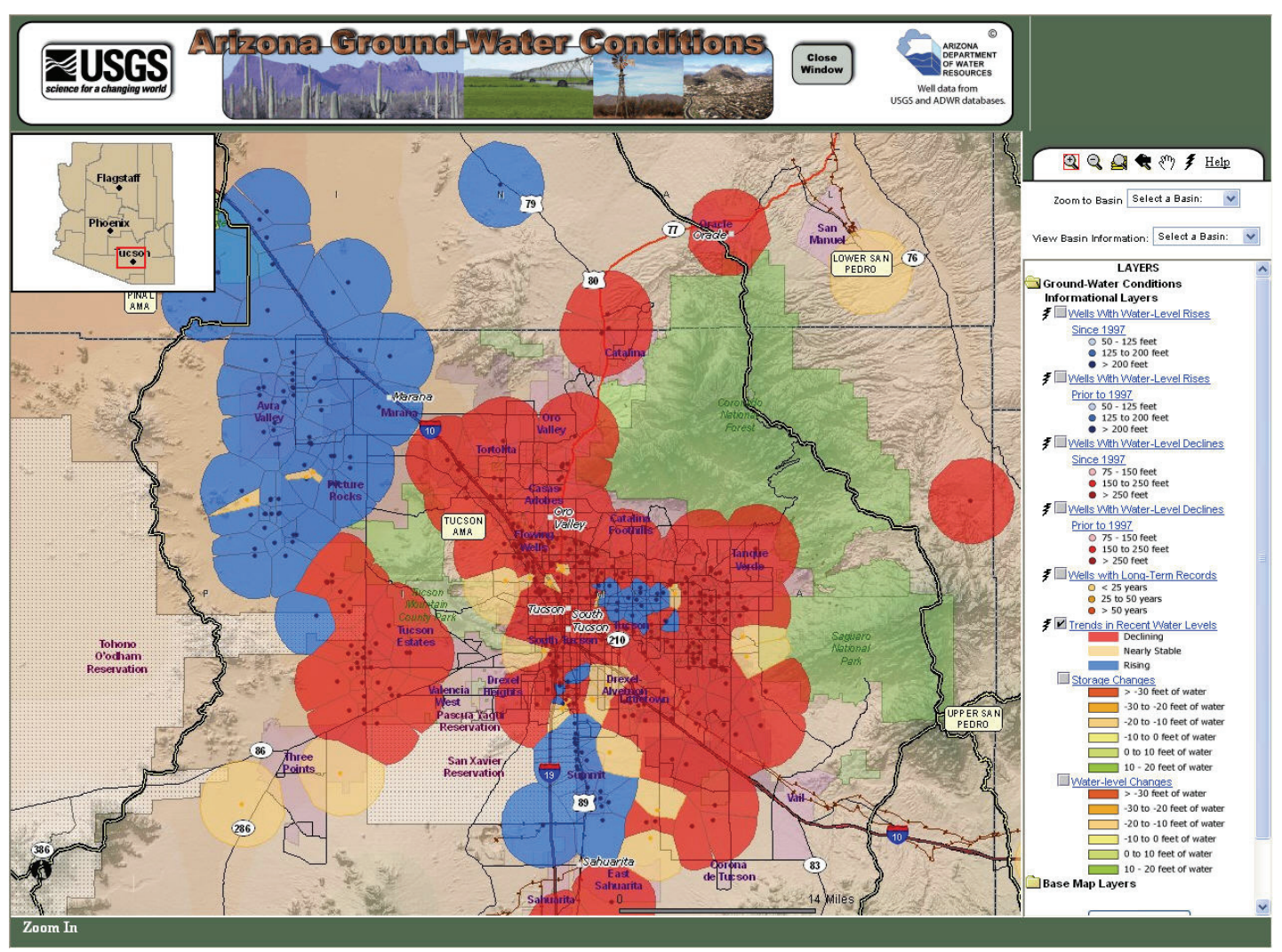

Figure 8. Screen capture of Arizona Ground-Water Conditions interactive map service demonstrating "Trends in Recent Ground-Water Levels" data layer.

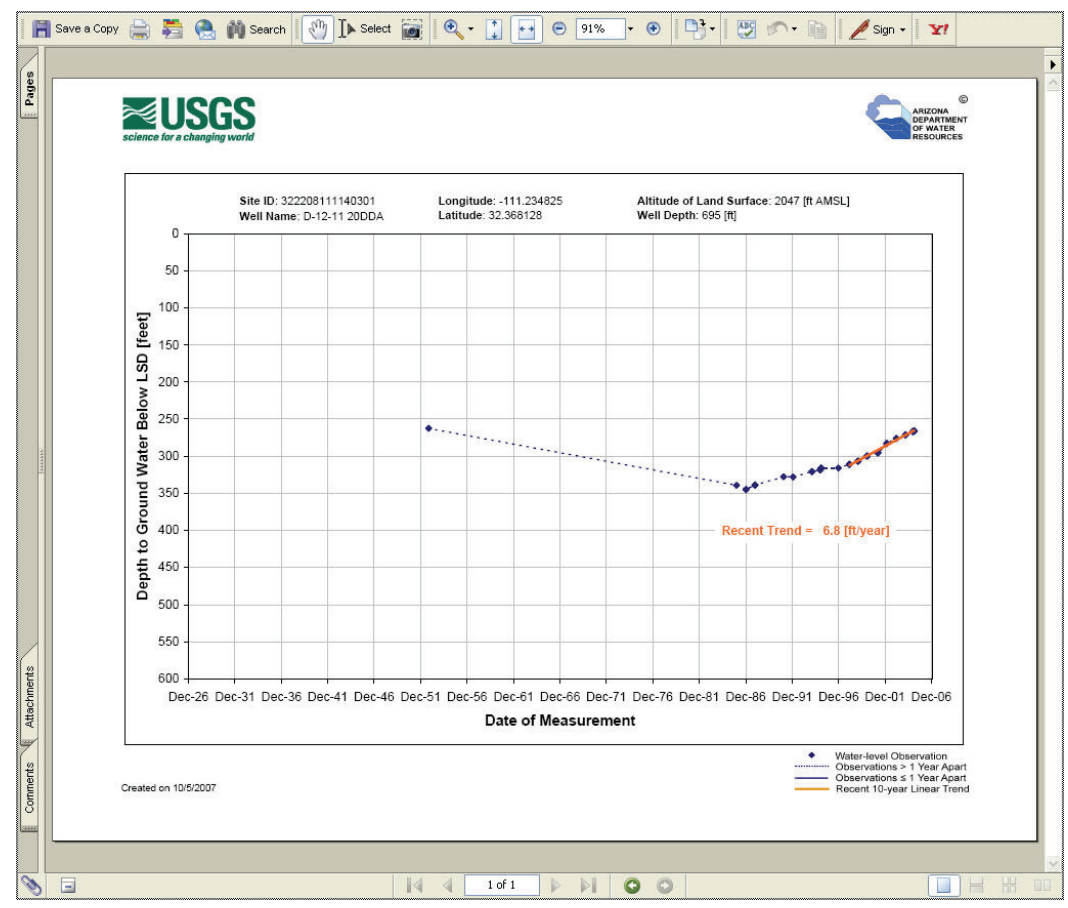

Figure 9. Example hydrograph of a well experiencing a rising recent trend in water level. Hydrographs are accessed through hyperlinks to the recent-trend polygons in the "Trends in Recent Ground-Water Levels" data layer. 
change may be defined as the volume of water released from storage in a unit volume of aquifer for a unit decline in head (Heath, 1983). Storage change since predevelopment is presented in units of length (feet) and is computed as the product of a storage-coefficient value and the change in water level since predevelopment. Storage coefficients are obtained from previously published reports and, depending on the type of aquifer, may be a specific yield or the product of specific storage and thickness.

In some areas, a lack of predevelopment information precludes determination of change in water levels and storage since predevelopment. As part of the development of these layers, water levels from predevelopment reports and maps were augmented with observations from the NWIS and ADWR databases, where appropriate. However, certain areas may contain no coverage, even if changes in water levels and storage have occurred, if no information on predevelopment conditions could be located.

Presentation of these layers in the Web-based IMS is done through a raster image that allows visualization of water-level and storage change of the completed areas by consistent color values across all areas (fig. 10). Warmer colors (red, orange, yellow) are used to indicate areas of greater decline in storage or water level since predevelopment. Cooler colors (green, blue) are used to indicate areas of greater rise in storage or water level. No hyperlinks are available with either of these layers.

While production of these two layers of information requires much hands-on effort, efficiency gains have been realized by developing a VBA program to aid in adding individual well information to both predevelopment and current water-level surfaces. This program selects all wells with observations in the date range supplied by the user, computes the average and standard deviation of water levels during the time period, and produces a GIS output file that is utilized by the IMS system to project this information. Additionally, as predevelopment water-level surfaces have now been completed for many basins and stored in a GIS environment, future updating of these data layers will only require the construction of new, current water-level surfaces.

\section{Additional Basin Information}

Additional basin information is made available on the IMS system that shows population projections and water withdrawals for different water use types. Water withdrawal information was obtained from two sources - ADWR and USGS. Values of water withdrawals for basins associated with AMAs and INAs were estimated by summing the pumpage of exempt (less than or equal to 35 gallons per minute) and non-exempt (greater than 35 gallons per minute) wells for each of the four primary water-use categories (irrigation, mining, municipal, and thermoelectric). It should be noted that reporting of pumpage by exempt wells is voluntary and that not all exempt well pumpage information will be reflected in the Wells55 Database. However, it is likely that most of the major water users in each category are from non-exempt wells and will therefore have reporting requirements. Information about water withdrawals for areas outside of the AMAs and INAs was provided by the USGS (Tadayon, 2005). Values for both datasets were rounded according to USGS practice (Tadayon, 2005). Current and projected population numbers for the counties were obtained from the ADES and are provided with no interpretation.

The "Other Basin Information" pages are accessed through a drop-down menu of basin names in the IMS system. Once a basin name is selected in the menu, a pop-up window appears with a pdf version of the information (fig. 11). A map on the page highlights the basin area and all counties represented in the basin. Yearly water withdrawals for the selected basin were totaled for the usage categories and are presented in a line chart for 1991 through 2004. Current and projected 


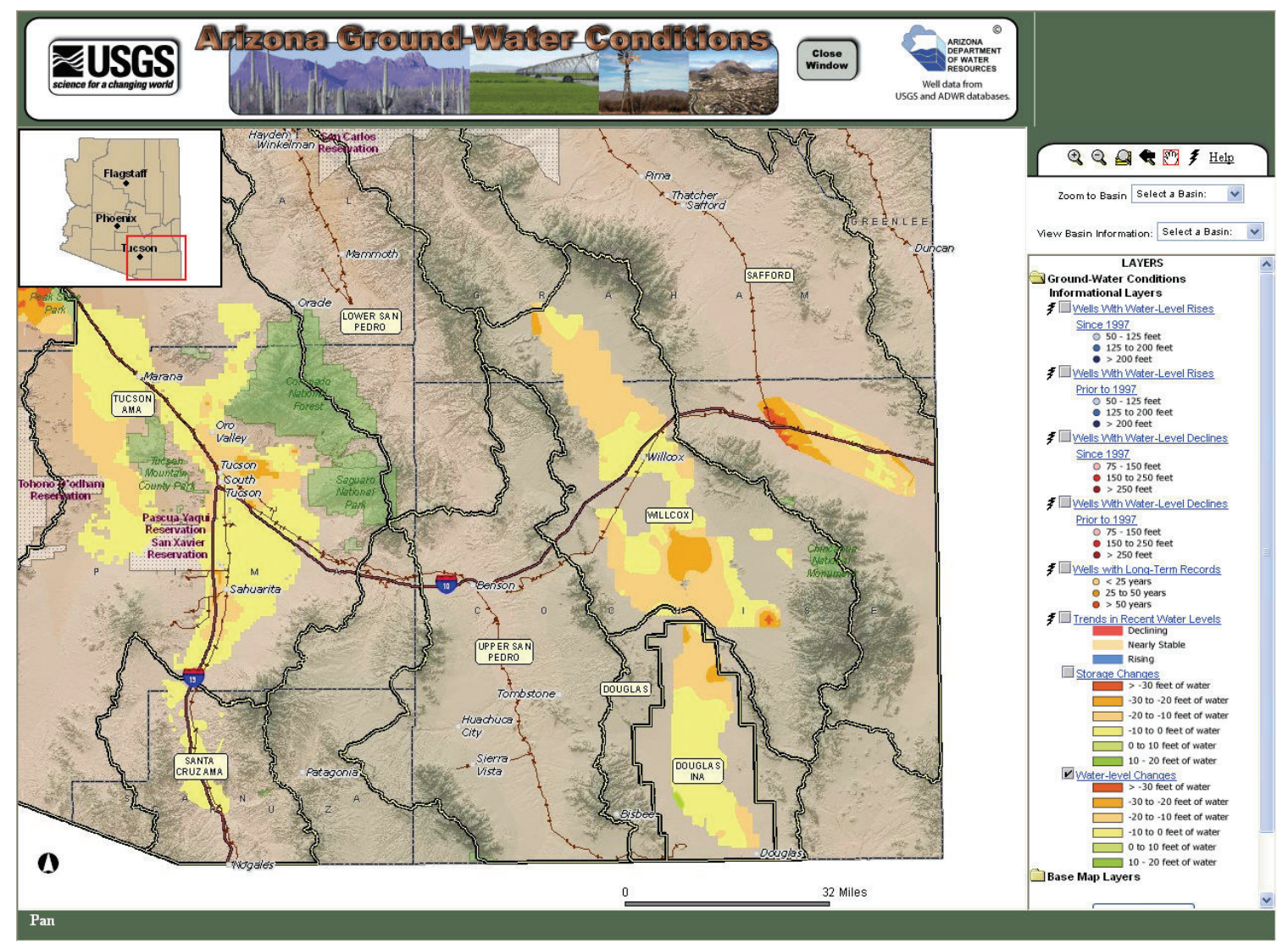

Figure 10. Screen capture of Arizona Ground-Water Conditions interactive map service demonstrating "Change in Water Level Since Predevelopment" data layer.

population for each of the highlighted counties is given in five-year increments through 2050. A brief list of literature resources related to the basin is also provided for further reading.

\section{Summary}

Unlike surface-water indicators such as stage or discharge, ground-water conditions may be more difficult to assess and present. Individual ground-water levels in wells are an illustrative measure of an aquifer system, but these point data do not give a good sense of the regional scale of conditions. Additionally, changes in ground-water conditions may involve time scales ranging from days to many years, depending on recharge, soil properties, and depth to the water table. The lack of an easily identifiable ground-water property indicative of current conditions and inclusive of differing time scales makes the presentation of ground-water conditions a challenging task, particularly on a regional basis. Publicly-available tools utilizing easy to understand ground-water information are needed to improve the value of existing datasets. The USGS Arizona GroundWater Conditions IMS is one approach to meet this need.

Computer software was created to "mine" existing water-level data from USGS and ADWR databases and aid in creating the data layers on the IMS system. Several layers of information covering different time periods and different aspects of ground-water conditions are available on the Web site, allowing users to see different details of the overall ground-water picture. Layers of wells with water-level declines give an indication of how aquifer systems have been depleted, both 


\section{McMullen Valley Basin}

Projected Population and Water Withdrawal Information

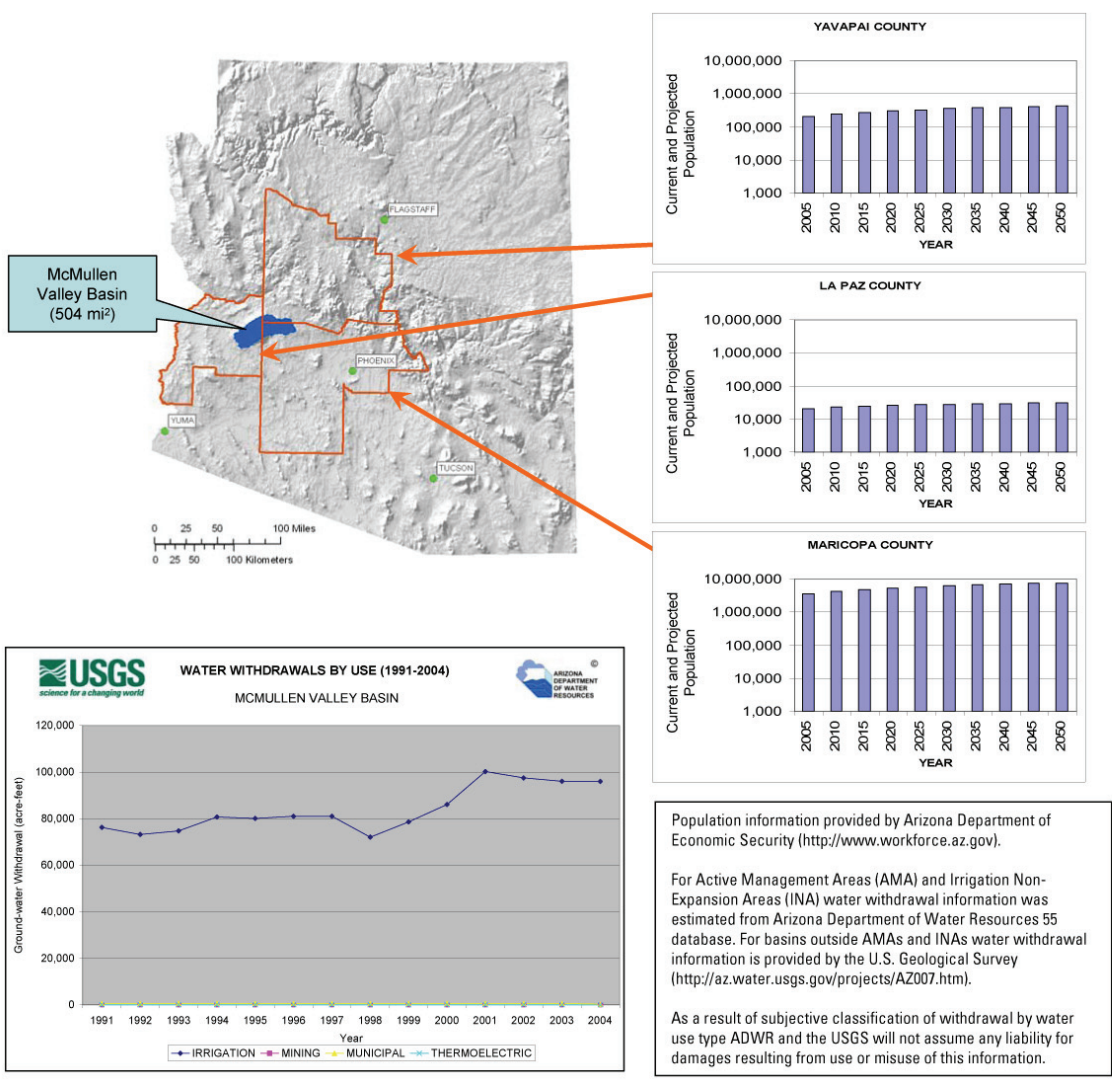

For More Information:

Arizona Water Commission, 1975, Annual report on ground water in AZ with emphasis on Gila Bend Basin, McMullen Valley and the southeast part of the Harquahala Plains-Spring 1973 to Spring 1974: AZ Water Commission Bulletin 9, Phoenix, 33 p.

Briggs, P. C., 1969, Ground-water conditions in McMullen Valley, Maricopa, Yavapai, and Yuma Counties, AZ: WaterResources Report 40, Arizona State Land Department and USGS Open-File Report, 31 p.

Freethey, G.W. and Anderson, T.W., 1986, Predevelopment hydrologic conditions in the alluvial basins of AZ and adjacent parts of CA and NW: USGS HA-664.

Kam, William, 1957, Interim report on the ground-water resources of McMullen Valley, Maricopa, Yavapai, and Yuma Counties, AZ: USGS Open-File Report 57-59.

Kam, William, 1961, Geology and ground-water resources of McMullen Valley, Maricopa, Yavapai, and Yuma Counties, AZ: Water-Resources Report 8, Arizona State Land Department, Phoenix, 72 p.

Kam, William, 1964, Geology and ground-water resources of McMullen Valley, Maricopa, Yavapai, and Yuma Counties, AZ: USGS Water-Supply Paper 1665, 64 p. and 1 plate.

Pool, D.R., 1987, Hydrogeology of McMullen Valley, West-Central AZ: USGS WRIR 87-4140, 51 p.

Remick, W.H, 1981, Maps showing ground-water conditions in the McMullen Valley area, Maricopa, Yavapai, and Yuma Counties, AZ-1981: AZ Department of Water Resources hydrologic Map Series Report 6.

Ross, C.P., 1922, Routes to desert watering places in the lower Gila region, AZ: USGS Water-Supply Paper 490-C, pp 271-315.

Ross, C.P.,1923, The lower Gila Region, AZ: USGS Water-Supply Paper 498, 237 p.

Figure 11. Example page of "basin information" including recent pumpage totals, current and projected population (by county) and a brief bibliography for further reading. These pages are accessed through hyperlinks to the basin name in the "Other Information" drop-down list. 
historically (prior to 1997) and continuing until present (since 1997). Layers of wells with waterlevel rises indicate areas that may have come back, in either past or current times. Long-term well records present information over the longest period available for the basins and may exhibit effects of development, management, and climate. A new method of recent trend analysis provides a depiction of areas whose water levels appear to be improving, worsening, or holding steady based on the most-recent 10-year record. Illustrative layers of changes in water levels and storage change since predevelopment are presented as an attempt to quantify changes in aquifer conditions since before large-scale human impacts for areas where predevelopment information is available. The use of consistent coloration across basins to identify levels of information for each data layer provides a visual overview of the region. For most layers, additional details are available through hydrographs that are hyperlinked to the well locations.

The analyses presented in this IMS system highlight the importance of frequent and consistent collection of ground-water level data. Additionally, it is important for ground-water levels to be monitored in rural areas in which development is foreseen or suspected in order to have a sufficient baseline from which to compare future impacts on the aquifer system. The Arizona Ground-Water Conditions IMS Web site will continue to be updated with new information as other alluvial basins in the Lower Colorado River Basin are investigated. However, updates of groundwater conditions will depend upon the availability of funding.

\section{References Cited}

Anderson, T.W., 1995, Summary of the Southwest Alluvial Basins, Regional Aquifer-System Analysis, south-central Arizona and parts of adjacent States: U.S. Geological Survey Professional Paper 1406-A, 33 p.

Heath, R.C., 1983, Basic ground-water hydrology: U.S. Geological Survey Water-Supply Paper $2220,86 \mathrm{p}$.

Konieczki, A.D., and Wilson, R.P., 1992, Annual summary of ground-water conditions in Arizona, spring 1986 to spring 1987: U.S. Geological Survey Open-File Report 92-54, 1 sheet.

Mumm, M., 2005, Voronoi diagrams: Montana Mathematics Enthusiast, v. 1, no. 2, p. 44-55.

Okabe, A., Boots, B., Sugihara, K., and Chiu, S.N., 2000, Spatial tessellations: Concepts and applications of Voronoi diagrams, 2nd edition: Hoboken, N. J., John Wiley, 696 p.

Tadayon, S., 2005, Water withdrawals for irrigation, municipal, mining, thermoelectric-power, and drainage uses in Arizona outside of active management areas, 1991-2000: U.S. Geological Survey Scientific Investigations Report 2004-5293, 28 p.

U.S. Geological Survey, 1984, National water summary 1983 - Hydrologic events and issues: U.S. Geological Survey Water-Supply Paper 2250, 243 p. 